\title{
MEMAHAMI DAN MENGELOLA TRANSFORMASI DIGITAL
}

Angelita Nauli Panggabean - 2301950881 - LB21

E-Business Strategy and Implementation

\begin{abstract}
Abstrak
Seiring perkembangan teknologi yang semakin pesat, perusahaan harus mampu beradaptasi dengan cepat dan efektif terhadap perubahan. Transformasi teknologi inilah yang merupakan proses objektif untuk merespons perubahan yang terjadi. Individu maupun perusahaan dituntut untuk melakukan transformasi digital. Dengan demikian, banyak perusahaan yang telah memulai untuk melakukan transformasi digital demi dapat beradaptasi dengan perubahan tersebut. Namun, transformasi digital tidak dapat dilakukan begitu saja, melainkan diperlukan pemahaman yang matang serta cara kelola transformasi digital yang efektif. Metode yang digunakan penulis adalah dengan mengumpulkan serta mempelajari jurnal-jurnal melalui internet untuk mencapai kesimpulan.
\end{abstract}

Kata Kunci: Transformasi Digital

\section{Pendahuluan}

Perkembangan teknologi telah mempengaruhi kegiatan yang dilakukan kita sehari-hari, dan telah menyebabkan ketergantungan pada penggunaan teknologi itu sendiri. Perkembangan teknologi yang hadir di tengah-tengah kita, pun menuntut, baik individu maupun organisasi untuk melakukan tranformasi digital. Transformasi digital merupakan sebuah proses dengan mengadopsi teknologi digital untuk mengubah proses yang ada sehingga menciptakan hal atau cara baru. Dengan kata lain, Transformasi digital merupakan perubahan suatu perusahaan atau organisasi yang melibatkan sumber daya manusia, proses, strategi, struktur, melalui adopsi teknologi untuk meningkatkan kinerja (Royyana, 2018). Semua yang terlibat perlu mengelola dan memahami bersama tentang kegiatan transformasi digital yang akan dilakukan. Salah satu tujuan dari transformasi digital adalah mengubah cara lama menjadi lebih efektif dan efisien, terutama dalam menjalankan bisnis. Misalnya, perusahaan akan diberikan kemudahan dalam melakukan proses pemasaran dan penjualan produknya melalui teknologi digital. Namun, transformasi digital tidak dapat dilakukan semudah yang dibayangkan, faktanya banyak strategi yang harus dilakukan dengan baik, serta beberapa faktor yang perlu pertimbangan oleh perusahaan. Oleh karena itu, telah membuat penulis tertarik untuk memahami dan mengetahui tentang cara serta dampak mengelola transformasi digital bagi perusahaan.

\section{Literature Review}

Istilah transformasi mengacu pada suatu perubahan dalam organisasi yang berdampak besar pada struktur organisasi itu sendiri. Transformasi digital didefinisikan sebagai penggunaan teknologi digital yang secara radikal dapat meningkatkan dan mencapai kinerja serta tujuan perusahaan yang diharapkan (Royyana, 2018). Transformasi digital juga dapat diartikan sebagai 
suatu proses yang bertujuan untuk meningkatkan suatu entitas dengan memicu perubahan yang signifikan pada propertinya melalui adopsi teknologi informasi, komputasi, komunikasi, serta konektivitas (Putri, Herdiana, Munawar, et al., 2021). Berdasarkan penelitian (Westerman, et al., 2011), bahwa transformasi digital menyinggung di tiga bagian utama organisasi, yakni pengalaman pelanggan, proses operasional, dan model bisnis. Dengan adanya transformasi digital, perusahaan tentu membutuhkan infrastruktur dan teknologi yang tepat serta platform untuk diimplementasikan.

Ada beberapa strategi dan faktor yang perlu dipertimbangkan dalam melakukan transformasi digital, salah satunya keamanan. Proses transformasi digital sangat memerlukan keamanan data yang baik dan efektif karena fakta membuktikan bahwa banyak terjadi ancaman kebocoran data digital serta kejahatan siber. Keamanan yang baik dan efektif melibatkan analisis yang menyeluruh, implementasi, memantau, dan memperbaharui (Putri, Herdiana, Suharya, et al., 2021). Selanjutnya, strategi perusahaan yang perlu dilakukan adalah dengan menyelaraskan kembali dan memulai proses perubahan mengenai struktur internal dan model bisnisnya. Hal ini karena, transformasi mengacu pada perubahan yang dapat berdampak besar pada strategi dan struktur organisasi. Selain itu, perlu juga untuk memahami mekanisme digitalisasi serta membangun pemahaman bersama di dalam organisasi (Putri, Herdiana, Suharya, et al., 2021). Hal ini karena, pemahaman yang buruk tentang digitalisasi dan pemahaman perusahaan akan menciptakan kegagalan strategi dan keputusan yang telah dibuat. Proses transformasi digital melibatkan pengembangan visi strategis, perencanaan, dan implementasi. Dalam pengembangan strategi tersebut manajer perusahaan memerlukan instrumen yang membantu dalam memahami fenomena dan keadaan organisasi saat ini, serta kerjasama dan komunikasi yang baik antara berbagai pihak.

Berdasarkan penelitian (Schwertner, 2017) pada UKM (Usaha Kecil dan Menengah) Bulgaria, bahwa transformasi digital pada bisnisnya adalah sangat penting untuk membangun keunggulan kompetitif serta menjaga daya saing pasar, baik lokal maupun internasional. Akan tetapi, kesulitan dan hambatan utama proses transformasi digital bukanlah teknologi, melainkan faktor manusia itu sendiri, seperti penolakan karyawan terhadap perubahan, kurangnya pengetahuan dan pengalaman digital karyawan, serta kurangnya motivasi. Penelitian (Hida Syahchari et al., n.d.) juga menyimpulkan, bahwa pengalaman digital karyawan berpengaruh signifikan terhadap perusahaan yang melakukan transformasi digital.

Transformasi digital berdampak pada organisasi dengan cara yang berbeda. Dampak terbesar yang diharapkan terjadi adalah pada proposisi nilai organisasi, segmen pelanggan yang dapat diidentifikasi dan dilayani, cara organisasi menjangkau para pelanggannya, serta sumber daya yang dimiliki. Berdasarkan, tinjauan literatur, dampak transformasi digital dapat dikelompokkan menjadi empat topik utama, antara lain dampak pada pelanggan dan hubungan pelanggan; dampak pada penciptaan nilai dan model bisnis; dampak pada internal perusahaan dan struktur organisasi; dan dampaknya terhadap proses dan efisiensi (Arpe \& Kurmann, 2019). Teknologi digital dapat mempengaruhi perilaku konsumen yang pada nantinya akan menjadi pendorong perusahaan dalam berinteraksi dengan pelanggan. Perusahaan akan dimudahkan dalam mengiklankan produk kepada pelanggan potensial secara luas tanpa dibatasi oleh batasan pasar. Selain itu, interaksi antara pelanggan dan perusahaan dapat semakin meningkatkan melalui saling bertukar informasi dan dapat langsung merespon dengan mudah. Misalnya, dengan menilai produk 
yang dibeli dan memberikan umpan balik kepada perusahaan di sosial media. Dengan begitu, perusahaan akan mengetahui apa yang diminati dan tidak diminati oleh konsumen.

\section{Metode}

Karya tulis ini dibuat dengan metode literature review atau tinjauan pustaka, dimana penulis mengumpulkan dan mempelajari jurnal-jurnal. Jurnal tersebut didapatkan dari berbagai sumber melalui internet.

\section{Kesimpulan}

Perubahan dan perkembangan teknologi yang semakin pesat, menuntut perusahaan untuk dapat beradaptasi dengan cepat dan efektif, salah satunya adalah melakukan transformasi digital. Transformasi digital adalah sebuah proses dengan mengadopsi teknologi digital untuk mengubah proses yang ada sehingga menciptakan hal atau cara baru. Transformasi digital sendiri memberikan dampak yang signifikan bagi perusahaan. Namun, melakukan transformasi digital merupakan hal yang tidak mudah, yakni membutuhkan strategi dan prioritas yang jelas yang didukung oleh seluruh pelaku, baik internal maupun eksternal perusahaan.

\section{Reference:}

Arpe, B., \& Kurmann, P. (2019). Supervisor: Matts Kärreman Managing Digital Transformation How organizations turn digital transformation into business practices Master's Programme in International Strategic Management.

Hida Syahchari, D., Saroso, H., Sudrajat, D., Grace Herlina, M., \& W Jordaan, H. K. (n.d.). The Influence Of Digital Employee Experience And Employee Agility: Do They Boost Firm's Effectiveness?

Putri, N. I., Herdiana, Y., Munawar, Z., \& Komalasari, R. (2021). Teknologi Pendidikan dan Transformasi Digital di Masa Pandemi COVID-19. Jurnal ICT : Information Communication \& Technology, 20(1), 53-57.

Putri, N. I., Herdiana, Y., Suharya, Y., \& Munawar, Z. (2021). Kajian Empiris Pada Transformasi Bisnis Digital (Vol. 7, Issue 1).

Royyana, A. (2018). Strategi Transformasi Digital Pada PT. Kimia Farma (Persero) TBK. In Jurnal Sistem Informasi Kesehatan Masyarakat Journal of Information Systems for Public Health (Vol. 3, Issue 3).

Schwertner, K. (2017). Digital transformation of business. Trakia Journal of Science, 15(Suppl.1), 388-393. https://doi.org/10.15547/tjs.2017.s.01.065

Westerman, G., Calméjane, C., Bonnet, D., Ferraris, P. \& McAfee, A. (2011). Digital Transformation: A Road-Map for Billion-Dollar Organizations (Report). Capgemini Consulting $\backslash \&$ MIT Center for Digital Business 